\title{
Investigation of the Challenges and Issues of Hydrogen and Hydrogen Fuel Cell Applications in Aviation
}

\author{
Fan Zhang ${ }^{\mathrm{a}, \mathrm{b}, *}$, Jon Maddy ${ }^{\mathrm{b}}$ \\ ${ }^{a}$ School of Engineering, Faculty of Computing, Engineering and Science, University of \\ South Wales, Pontypridd, Wales, CF37 1DL, United Kingdom \\ ${ }^{b}$ Sustainable Environment Research Centre, Faculty of Computing, Engineering and \\ Science, University of South Wales, Pontypridd, Wales, CF37 1DL, United Kingdom
}

\begin{abstract}
Aviation is an vital global industry that generates economic growth, creates jobs and facilitates national and international trade and tourism. During the Covid-19 pandemic, the world had seen a sharp decline in commercial air travel due to the worldwide travel restrictions, lock-down orders and widespread fear of infection. However, there is a rapid increase in the use of UAVs for surveillance, communication, delivery and transport. And the aviation industry is believed to be able to provide valid contribution to the postpandemic economic recovery. In order to reduce the carbon emission from aviation industry, there is a requirement for more electric aircraft. Hydrogen and fuel cell system's capability of creating a clean road transportation have been widely tested. In this paper, the status of hydrogen and fuel cell utilised in aviation is reviewed, and the challenges and issues are identified for a better integration of the hydrogen and fuel cell system in aviation.
\end{abstract}

Keywords: Hydrogen energy, Fuel cell, Aviation, Electric aircraft, Electric drones

\section{Introduction}

Aviation is an important global industry that connects people, cultures and businesses across cities, countries and continents. It generates economic growth, creates jobs, facilitates national and international trade and tourism.

\footnotetext{
*Corresponding author. Tel: 00441639814510 / 00441443482209

Email address: fan.zhang@southwales.ac.uk, fanvac@gmail.com (Fan Zhang)
} 
According to [1], published in 2019, year-over-year traffic has an average of $6.7 \%$ growth during the past five years, and it is projected that by 2038 , the total number of jets in operation will be doubled, to reach 50,660 compared with 25,830 jets in 2019. Despite the significant negative impact on the global economy and the operation of airlines due to COVID-19 pandemic, it is been recognised by International Air Transport Association (IATA) that in order to support the recovery in economic development in the post-COVID period, restoring air transport connectivity will be critical [2].

Recent years and particularly during the COVID-19 pandemic, the world has seen unmanned aerial vehicles (UAVs), commonly known as "drones", to have the potential to be an iconic technology in the near future. Drones, initially designed for military surveillance and conventionally powered by either battery or combustion engines, have been widely adopted by various industries. The applications range from aerial photography, entertainment, precision agriculture, search and rescue, to weather forecast, wildlife monitoring, and enforcement of law and environmental regulations. Drone technology has also shown its importance in the monitoring and sensing for academic research studies, industrial emission and leaking monitoring [3], and there is an intense discussion of plausibility and benefits of using drones for parcel delivery and passenger transport [4]. During the COVID-19 lock down, as people are stay indoors and only go out to meet essential needs while following the social distancing in order to reduce the rate of infection, it is believed that drones can help in delivery of medicines, goods, samples to health care system, and monitoring public compliance of the social distancing rules $[5,6]$.

Despite the long-term investments in technological innovation made by aircraft and engine manufacturers, the rapid growth of the air traffic still results in the high growth in carbon emission. Recent study carried out by International Council on Clean Transportation (ICCT) unveiled that carbon dioxide emitted by airlines increased by $32 \%$ from 2013 to 2018 . The $5.7 \%$ compound annual growth rate (CAGR) of emissions, is $70 \%$ higher compared with an average of $3.3 \%$ estimated by the International Civil Aviation Organisation (ICAO) [7]. It is argued by European Commission that global international aviation emissions are projected to be around $70 \%$ higher than in 2005 and ICAO forecasts that by 2050 this can grow by a further $300-700 \%$ [8]. 
According to the latest annual Emissions Gap Report published by UN Environment Programme in 2019, in order to meet the projected emissions levels for $2^{\circ} \mathrm{C}$ and $1.5^{\circ} \mathrm{C}$, there is a requirement to cut emissions at 2.7 per cent per year from 2020 for the $2^{\circ} \mathrm{C}$ goal and 7.6 per cent per year on average for the $1.5^{\circ} \mathrm{C}$ goal. It is clear that greater cuts will be required if this reduction target is delayed [9].

In order to contribute to the global target and further reduce the carbon emission from aviation industry, Aerospace Technology Institute (ATI) developed its four main strategic themes in 2016 [10]:

- Aircraft of the future: strengthen the whole-aircraft design and system integration capability;

- Smart, connected and more electric aircraft: develop advanced systems technologies to capture high-value opportunities;

- Aerostructure of the future: development of large complex structures, wings in particular;

- Propulsion of the future: advance new generation of more efficient propulsion technologies.

There are a number of projects focusing on developing electric aircraft as details are listed in Table 1. It must be seen that majority of the projects centred on general aviation or recreational aircraft which is limited to single or a small number of seats, only a handful of projects targeted the commercial aircraft. However, they are all on the initial testing stage, i.e. initial component testing, partially replacing existing engine with high power motor, etc. The main obstacle is the low gravimetric energy density of batteries used as the main power source.

Similarly, electric UAVs bring a number of features such as reliability, reduced noise and thermal signatures, high efficiency, no pollutant emissions, self-starting, and the developed control devices enables high manoeuvrability as revealed by [11]. However, the authors also argued that battery's low energy density prevents the UAVs to have a sufficient flight time. Additionally, due to its slow power dynamics, battery may not allow an UAV to conduct 
some manoeuvres needing fast power response.

By considering the overall efficiency of the both conventional and electrical propulsion systems, [12] concluded that a kilogram of kerosene contains usable energy that is equivalent to the electrical energy stored by 12-13 kilogram of batteries. In other words, it requires 9-10 kilogram of batteries to replace 1 litre of kerosene. Several researches also indicated that battery energy densities should between $750-1000 \mathrm{Wh} / \mathrm{kg}$ for practical use $[13,14]$ which is unlikely to be achieved according to current roadmap on battery development [15-17]. 
Table 1: Brief summary of current electric aircraft projects

\begin{tabular}{|c|c|c|c|c|}
\hline Project & Type & Category & Technical Aspects & Ref \\
\hline $\begin{array}{l}\text { Airbus / Siemens / Rolls } \\
\text { Royce: E-Fan X }\end{array}$ & $\begin{array}{l}\text { Hybrid- } \\
\text { electric }\end{array}$ & $\begin{array}{l}\text { Large } \\
\text { commercial } \\
\text { aircraft }\end{array}$ & $\begin{array}{l}\text { Based on British Aerospace RJ100, replace one of } \\
\text { four gas turbines with a } 2 \mathrm{MW} \text { electric motor. }\end{array}$ & {$[18]$} \\
\hline $\begin{array}{l}\text { Ampaire: TailWind / } \\
\text { Ampaire } 337\end{array}$ & $\begin{array}{l}\text { Electric / } \\
\text { Hybrid- } \\
\text { electric }\end{array}$ & $\begin{array}{l}\text { Business } \\
\text { aircraft }\end{array}$ & $\begin{array}{l}\text { Conceptual design. Currently, testing the } \\
\text { Ampaire 337, based on the six-seat Cessna } 337 \\
\text { Skymaster. The battery-powered electric motor } \\
\text { replaces a combustion engine of the aircraft's } \\
\text { original two-engine configuration to form a } \\
\text { 'parallel hybrid' aircraft. }\end{array}$ & {$[19]$} \\
\hline Eviation: Alice & Electric & $\begin{array}{l}\text { Business } \\
\text { aircraft }\end{array}$ & $\begin{array}{l}\text { 11-seat business aircraft ( } 9 \text { passengers and } 2 \\
\text { crew) powered by } 920 \mathrm{kWh} \text { Lithium-ion battery } \\
\text { which weighted of } 3600 \mathrm{~kg} \text {, approximately } 60 \% \text { of } \\
\text { MTOW. The powerplant will provide } 900 \mathrm{~kW} \\
\text { peak power output and } 260 \mathrm{~kW} \text { for cruising. }\end{array}$ & {$[20]$} \\
\hline
\end{tabular}


Extra aircraft / Siemens:

Extra 330LE

o

\section{Electric}

General

aviation /

recreational

aircraft
Based on the German-built Extra 300L, a

two-seat aerobatic aircraft. Reached an altitude of 3,000 $\mathrm{m}$ in just four minutes and 22 seconds at a velocity of $11.5 \mathrm{~m} / \mathrm{s}$, which was officially recognised as a climb performance world record in 2016. Extra 330LE aircraft are powered by an electric SP260D motor with a power output of $260 \mathrm{~kW}(348 \mathrm{hp})$. The aircraft features two battery packs, each with 14 high-power Li-Ion battery modules with a capacity of $18.6 \mathrm{kWh}$. The companies aim to demonstrate an aircraft with 100 passengers by 2020, and reach range of $1,000 \mathrm{~km}$ by 2030 .

\begin{tabular}{|c|c|c|c|}
\hline $\begin{array}{l}\text { Kitty Hawk: Flyer \& } \\
\text { Heaviside }\end{array}$ & Electric & VTOL & $\begin{array}{l}\text { Flyer: all electric, single seater VTOL vehicle, } \\
\text { powered by lithium polymer batteries. Using } 10 \\
\text { independent lift fans, the Flyer operates between } \\
3-10 \text { feet off the water. Heaviside: the latest } \\
\text { VTOL vehicle under development. }\end{array}$ \\
\hline Lilium & Electric & VTOL & $\begin{array}{l}\text { Conceptual design for } 4 \text { passengers and a pilot } \\
\text { with } 300 \mathrm{~km} \text { range and speed of } 300 \mathrm{~km} / \mathrm{h} \text {, } \\
\text { powered by } 36 \text { all-electric engines. }\end{array}$ \\
\hline
\end{tabular}




\begin{tabular}{|c|c|c|c|c|}
\hline NASA: X-57 Maxwell & Electric & $\begin{array}{l}\text { General } \\
\text { Aviation / } \\
\text { recreational } \\
\text { aircraft }\end{array}$ & $\begin{array}{l}\text { Based on a baseline Italian Tecnam P2006T. } \\
\text { Final configuration will have } 14 \text { electric motors } \\
\text { and propellers: } 12 \text { high-lift motors ( } 10.5 \mathrm{~kW} \\
\text { each) along the leading edge of the wing and two } \\
\text { large wingtip cruise motors ( } 60 \mathrm{~kW} \text { each). } \\
\text { Powered by } 69.1 \mathrm{kWh} \text { ( } 47 \mathrm{kwh} \text { usable) lithium } \\
\text { ion battery pack. }\end{array}$ & [24] \\
\hline Pipistrel: Alpha Electro & Electric & $\begin{array}{l}\text { General } \\
\text { Aviation / } \\
\text { recreational } \\
\text { aircraft }\end{array}$ & $\begin{array}{l}\text { 2-seat electric trainer for flight schools. With an } \\
\text { endurance of one hour plus a } 30 \text {-minute reserve, } \\
\text { the Alpha Electro is powered by a } 21 k W h \\
\text { battery pack and a } 60+k W \text { electric motor. }\end{array}$ & [25] \\
\hline $\begin{array}{l}\text { SolarImpulse Foundation: } \\
\text { Solar Impulse } 2\end{array}$ & Electric & $\begin{array}{l}\text { General } \\
\text { aviation / } \\
\text { recreational } \\
\text { aircraft }\end{array}$ & $\begin{array}{l}\text { Single pilot aircraft powered by } 17,248 \\
\text { photovoltaic solar cells with } 4 \text { engines of } 13.5 \mathrm{kWp} \\
\text { power output. As the PV cells are all installed on } \\
\text { the top of the aircraft wing, has the wingspan of } \\
\text { a B- } 747 \text { Jumbo Jet of } 72 \mathrm{~m} \text {. }\end{array}$ & [26] \\
\hline Uber Elevate & Electric & VTOL & $\begin{array}{l}\text { Conceptual design, requirements include } 150 \mathrm{mph} \\
\text { cruise speed, } 60 \text {-mile sizing range, a } 3 \text {-hour sprint } \\
\text { of } 25 \text {-mile trips, and capacity for one pilot and } 4 \\
\text { riders. }\end{array}$ & [27] \\
\hline Volocopter: VoloCity & Electric & VTOL & $\begin{array}{l}\text { 2-seater aircraft powered by } 9 \text { lithium-ion battery } \\
\text { pack and } 18 \text { brushless DC electric motor, with a } \\
\text { range of } 35 \mathrm{~km} \text { and maximum airspeed of } 11 \mathrm{~km} / \mathrm{h}\end{array}$ & [28] \\
\hline
\end{tabular}




\begin{tabular}{lllll}
\hline $\begin{array}{l}\text { Wright Electric / Easy Jet: } \\
\text { Wright } 1\end{array}$ & Electric & $\begin{array}{l}\text { Large } \\
\text { commercial } \\
\text { aircraft }\end{array}$ & $\begin{array}{l}\text { Designed aircraft for 186 passengers, powered by } \\
\text { a 1.5 MW electric motor and a 3-kilovolt inverter. }\end{array}$ & [29] \\
\hline Zunum Aero: ZA10 & $\begin{array}{l}\text { Hybrid- } \\
\text { electric }\end{array}$ & $\begin{array}{l}\text { Business } \\
\text { aircraft }\end{array}$ & $\begin{array}{l}\text { Modified Rockwell Turbo Commander } 840 \text { as } \\
\text { flying testbed which has similar weight and } \\
\text { performance to the 12 seats ZA10. Powered by } \\
\text { propulsion batteries, and a Safran turboshaft. }\end{array}$ & [30] \\
\hline
\end{tabular}


Another important factor needs to be considered when using batteries for transportation is the charging time. The charging leads to a conflict of interest in commercial transport, particularly when the battery needs to be charged during normal operating hours. During this period, vehicles powered by batteries are unusable which affects their availability. In order to cope with the battery charging, there are research efforts go into understanding the charging behaviour of battery and hence help to plan the economic activities in terms of locations, time and energy, depending on the state of charge (SOC) of the battery [31]. The long battery charging time is more problematic when considering use batteries in aviation, especially during long range flight missions.

Hydrogen, the most abundant element on Earth and its used as an energy vector has been widely explored. Hydrogen can be produced from various feed-stocks via various routes, can be stored as gas, liquid or metal hydride, and can be used to generate both electricity and heat in a number of different applications [32]. Research work have shown that hydrogen can be used as a promising alternative for future aircraft fuel, due to its high energy content and favorable combustion kinetics to reduce environmental impact and to increase sustainability [33]. [34] investigated the potential of utilising liquid hydrogen to replace the conventional Jet A fuel for clean commercial air transport. The results suggested that total cumulative emissions of greenhouse gas (GHG) can be stabilised, even reduced to and below the specified target level by gradually replacing the Jet A with liquid hydrogen as fuel for aircraft fleet. The author claimed that clean commercial air transportation can be achieved in the long-term future despite the continuous growth of air transport demand. Bicer \& Dincer [35] evaluated the overall life cycle of an aircraft running on conventional jet fuel and alternative fuels including hydrogen, liquid natural gas, ammonia, and methanol. The well-to-wake approach considered the production of ammonia and hydrogen fuels via conventional and renewable routes. The results illustrated that hydrogen and liquefied natural gas are more environmentally benign alternatives compared with other fuel types. [36] evaluated the well-to-wake energy consumption in aviation between conventional Jet $\mathrm{A}$ fuel and alternative fuels as liquid natural gas (LNG) and liquid hydrogen (LH2). By analysing two types of flights, i.e., short flights $(<5000 \mathrm{~km})$ and long flights $(>5000 \mathrm{~km})$ for six typical aircraft, the authors verified that even LH2 produced from steam methane reforming (SMR) can provide between 13\% and 21\% less environmental and 
social impacts than Jet A fuel, in the same aircraft. Furthermore, if LH2 is produced by electrolysis using electricity generated from renewable resources, such as hydro, photovoltaic (PV) or wind, compared with Jet A fuel, better reduction in environmental costs (upto 60\%) and energy consumption (upto $19 \%$ ), and less fossil fuel consumption (upto 80\%) can be achieved. Koroneos et al. [37] conducted a life cycle analysis of the production and the use of aviation fuel in different types of aircraft. The environmental impacts of kerosene and hydrogen, produced from steam methane reforming, solar PV energy, solar thermal energy, wind energy, hydro energy and biomass were evaluated. They concluded that hydrogen from renewable sources shows less environmental impacts in terms of GHGs emissions, acidification and winter smog. [38] compared the energy efficiency between kerosene- and hydrogenfuelled aircraft. The investigation demonstrated that due to the large fuel loads, long-range (as indicated in Table 4) transport aircraft can benefit from a significant reduction in fuel weight when converted to hydrogen, which resulted an increase in energy efficiency of up to $12 \%$ compared to kerosene. However, on the other hand, for short-to-medium-range aircraft, the adoption of hydrogen leads to an increase in the mission energy requirement of $5-18 \%$. This is mainly due to their short design range of the aircraft hence reduction in fuel weight is too small to nullify the increased structural weight. The author also found out that for all but the smallest aircraft, a cross-over range exists where both fuels result in the same energy efficiency. This cross-over range lies around 5,000 (for 300-passenger design) to 7,000 (for 400-passenger design) nautical miles. [39] compared the energy efficiency and effect on the environmental between traditional aircraft, more electric aircraft, and liquid hydrogen-fuelled aircraft in the cruise phase of a long-range flight. Based on the comparison, the authors suggested that the future aircraft concept for long distance flights is the combination of the more electric concept and the liquid hydrogen fuelled concept. This concept is better than the traditional aircraft in terms of increased energy efficiency and decreased harmful environmental effects.

Besides the research articles evaluating the plausibility and benefits of adopting hydrogen in aviation industry, there are also review papers in literature provided an overview of the current development of hydrogen technology for aviation applications. [40] investigated the use of hydrogen and fuel cell technology in the aviation and aerospace sectors. In this review, the authors covered the use of hydrogen as a propulsion fuel, as well as the 
use of hydrogen and fuel cell system as Auxiliary Power Unit (APU), for ground support equipment (GSE), and for UAVs and passengers aircraft. The authors also summarised the hydrogen production and storage technology. They concluded the challenges and future developments of hydrogen technology in the aviation industry as follows:

- The infrastructure for hydrogen storage and refuelling at airport

- The ability to produce high-quality hydrogen in a cost-effective manner and deliver it safely to the end users.

- To reduce the initial and operational costs of the hydrogen production technologies to make it more competitive

- Development of light-weight, cost-effective, and safe hydrogen storage technology.

- Effective burning of hydrogen as jet fuel

- The low power density of fuel cell system

In the review by Cecere et al. [41], through the history of hydrogen used as propellant and the utilisation of hydrogen fuelled engines in both low and high Mach number flights, the authors highlighted hydrogen as the best candidate for long range transportation with potentially zero emissions. As the article focused on hydrogen fuelled engines, they also discussed technical challenges associated with its usage, such as the development of tanks for cryogenic liquid storage, the development of efficient heat exchange systems for cooling the air entering into the combustion chamber (hypersonic applications), and the development of strategies to limit and control the effects of strong thermal stresses in the structural parts.

However, there is a need to gain thorough understanding of technical challenges and potential issues yet to be addressed for broader utilisation of hydrogen and fuel cell system for aviation industry. Compared with gas turbine, the fuel cell system is believed to be the optimal way of converting chemical energy in hydrogen into electrical and thermal energy with minimum carbon impact. Especially when hydrogen is produced from renewable resources, there is no GHG emissions at all. As the fuel cell system can operate independent of the engine, apart from providing electric power during 


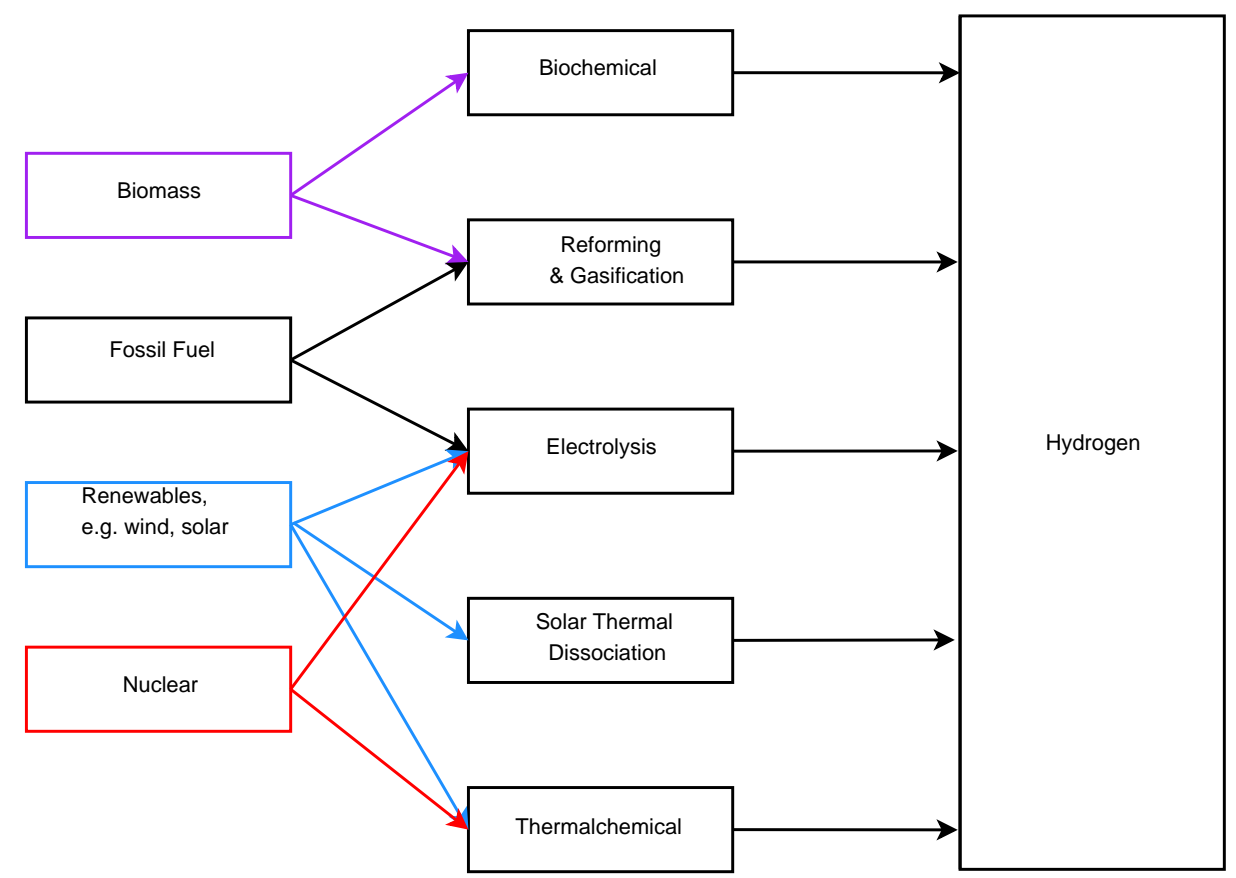

Figure 1: The feedstock and route of hydrogen production [32]

the flight and on the ground, the system can also produce water and inert gas and further reduce the noise, emissions and fuel consumption [42, 43].

Therefore, the aim of the paper is to provide an elaborate overview of the challenges faced by adopting hydrogen and hydrogen fuel cell technology for aviation, for both aircraft and UAVs, and performed as propulsion and other auxiliary power supply and provide other functionalities.

\section{Brief overview of hydrogen and fuel cell technology}

Hydrogen is the most abundant element on Earth. Although pure hydrogen is very uncommon in the Earth's atmosphere, it can be produced via various routes using wide range of feedstocks. As illustrated in Figure 1, hydrogen can be produced using biomass, fossil fuel, or using energy generated from renewable sources or nuclear power plant. There are huge number of publications covered the hydrogen technology, from its production, storage to application in various areas, including transportation, stationary and 
Table 2: Some characteristics of various fuels (adapted from [44])

\begin{tabular}{|c|c|c|c|c|}
\hline Fuel & $\begin{array}{r}\text { Energy (per } \\
\text { unit mass) }\end{array}$ & $\begin{array}{r}\text { Energy (per } \\
\text { unit vol.) }\end{array}$ & $\begin{array}{r}\text { Temperature } \\
\left({ }^{\circ} C\right)\end{array}$ & $\begin{array}{r}\text { Mass (per } \\
\text { unit vol.) }\end{array}$ \\
\hline Gasoline & 1 & 1 & 25 & 1 \\
\hline JP-5 & 0.97 & 1.1 & 25 & 1 \\
\hline Methanol & 0.44 & 0.51 & 25 & 1.1 \\
\hline $\begin{array}{l}\text { Liquid } \\
\text { hydrogen }\end{array}$ & 0.61 & 0.27 & -253 & 0.1 \\
\hline $\begin{array}{l}\text { Metal } \\
\text { hydride } \\
\text { (hydrogen) }\end{array}$ & 0.046 & 0.36 & 25 & 2.5 \\
\hline $\begin{array}{l}\text { Methane } \\
(3,000 \text { psi) }\end{array}$ & 1.1 & 0.29 & 25 & 0.25 \\
\hline $\begin{array}{l}\text { Hydrogen } \\
\text { gas }(3,000 \\
\text { psi) }\end{array}$ & 2.6 & 0.06 & 25 & 0.02 \\
\hline $\begin{array}{l}\text { Liquid } \\
\text { propane } \\
\text { (125 psi) }\end{array}$ & 1 & 0.86 & 25 & 0.73 \\
\hline $\begin{array}{l}\text { Hydrogen } \\
(10,000 \text { psi) }\end{array}$ & 2.6 & 0.2 & 25 & 0.08 \\
\hline $\begin{array}{l}\text { Methane gas } \\
(10,000 \text { psi) }\end{array}$ & 1.1 & 0.97 & 25 & 0.81 \\
\hline
\end{tabular}


Table 3: Specifications of the alternative aviation fuels [35]

\begin{tabular}{|c|c|c|c|}
\hline Fuel & $\begin{array}{r}\text { Specific energy } \\
(\mathrm{MJ} / \mathrm{kg})\end{array}$ & $\begin{array}{r}\text { Density at } \\
15^{\circ} \mathrm{C}\left(\mathrm{g} / \mathrm{m}^{3}\right)\end{array}$ & $\begin{array}{r}\text { Energy density } \\
(\mathrm{MJ} / \mathrm{L})\end{array}$ \\
\hline $\begin{array}{l}\text { Kerosene (Jet A/Jet } \\
\text { A-1) }\end{array}$ & 43.2 & 0.808 & 34.9 \\
\hline Liquid hydrogen & 120 & 0.071 & 8.4 \\
\hline Liquid methane & 50 & 0.424 & 21.2 \\
\hline Methanol & 19.9 & 0.796 & 15.9 \\
\hline Ethanol & 27.2 & 0.794 & 21.6 \\
\hline Biodiesel & 38.9 & 0.87 & 33.9 \\
\hline LIquid ammonia & 18.6 & 0.73 & 13.6 \\
\hline
\end{tabular}

Table 4: Parameters for the different aircraft categories [38]

\begin{tabular}{lrrrrrr}
\hline \hline Category & $\begin{array}{r}\text { Range } \\
{[\mathrm{km}]}\end{array}$ & $\begin{array}{r}\text { Nr. } \\
\text { Pax [-] }\end{array}$ & $\begin{array}{r}\text { Mach } \\
\text { Nr [-] }\end{array}$ & $\begin{array}{r}\text { Ceiling } \\
{[\mathrm{ft}]}\end{array}$ & $\begin{array}{r}\text { Field } \\
\text { length } \\
{[\mathrm{ft}]}\end{array}$ & $V_{\text {app }}[k t s]$ \\
\hline \hline Short range & 4,000 & 150 & 0.80 & 39,000 & 7,000 & 135 \\
Medium range & 9,000 & 300 & 0.82 & 41,000 & 9,000 & 140 \\
Long range & 14,000 & 400 & 0.84 & 43,000 & 12,000 & 150 \\
\hline \hline
\end{tabular}


portable $[45,46]$. The conventional hydrogen production using fossil fuel by means of steam-methane reforming, gasification, partial oxidation or using the electricity generated from fossil fuel via electrolysis to decompose water into hydrogen and oxygen is classified as "Brown Hydrogen" or "Grey Hydrogen". During these processes, there is significant amount of $\mathrm{CO}_{2}$ emission into the atmosphere. Where hydrogen produced using renewable electricity is classified as "Green Hydrogen" as there is no green house gas emission [47]. Therefore, when Green Hydrogen is used as aviation fuel, it will significantly reduce the carbon emission of aviation industry.

Compared with other alternative fuels, as shown in Table 2 and 3, hydrogen, in both gaseous and liquid form, has much high gravimetric energy density than other alternative fuels, which makes it a promising candidate to replace the existing fossil fuel based supply. However, direct combustion of hydrogen with air is not the optimal way as it will result in the generation of oxides of nitrogen $\left(N O_{x}\right)$, while fuel cell is a better alternative to generate both electrical and thermal energy from hydrogen.

A fuel cell is an electrochemical device used to transfer the chemical energy in the fuel into electrical and thermal energy. Hydrogen is a common fuel to be used in fuel cell systems. During this process, there is no GHG emission and the only by-product is water. Currently, there are six types of fuel cells available on the commercial market, which are:

- Proton Exchange Membrane Fuel Cell (PEMFC)

- Direct Methanol Fuel Cell (DMFC)

- Alkaline Fuel Cell (AFC)

- Phosphoric Acid Fuel Cell (PAFC)

- Molten Carbonate Fuel Cell (MCFC)

- Solid Oxide Fuel Cell (SOFC)

Other types of fuel cell technology are available and are under research and development, including Direct Ammonia Fuel Cells, Direct Ethanol Fuel 
Table 5: Key specifications of major fuel cells (table adapted from [32])

\begin{tabular}{|c|c|c|c|c|}
\hline $\begin{array}{l}\mathrm{FC} \\
\text { type }\end{array}$ & $\begin{array}{l}\text { Tempera- } \\
\text { ture }\left({ }^{\circ} \mathrm{C}\right)\end{array}$ & Reactions & Electrolyte & $\begin{array}{l}\text { Effiency } \\
(\%)\end{array}$ \\
\hline \multirow{2}{*}{\multicolumn{2}{|c|}{ PEMFC60-140 }} & Anode: $H_{2} \rightarrow 2 H^{+}+2 e^{-}$ & Polymer & 55 \\
\hline & & $\begin{array}{l}\text { Cathode: } \\
\frac{1}{2} \mathrm{O}_{2}+2 \mathrm{H}^{+}+2 e^{-} \rightarrow \mathrm{H}_{2} \mathrm{O}\end{array}$ & & \\
\hline \multirow[t]{5}{*}{ DMFC } & $30-80$ & Anode: & Polymer & 30 \\
\hline & & $\mathrm{CH}_{3} \mathrm{OH}+\mathrm{H}_{2} \mathrm{O} \rightarrow$ & & \\
\hline & & $\mathrm{CO}_{2}+6 \mathrm{H}^{+}+6 e^{-}$ & & \\
\hline & & Cathode: & & \\
\hline & & $\frac{3}{2} \mathrm{O}_{2}+6 \mathrm{H}^{+}+6 e^{-} \rightarrow 3 \mathrm{H}_{2} \mathrm{O}$ & & \\
\hline \multirow[t]{4}{*}{$\mathrm{AFC}$} & $150-200$ & Anode: $\mathrm{H}_{2}+2 \mathrm{OH}^{-} \rightarrow$ & Potassium & 60 \\
\hline & & $\mathrm{H}_{2} \mathrm{O}+2 e^{-}$ & hydroxide & \\
\hline & & Cathode: & & \\
\hline & & $\frac{1}{2} \mathrm{O}_{2}+\mathrm{H}_{2} \mathrm{O}+2 e^{-} \rightarrow 2 \mathrm{OH}^{-}$ & & \\
\hline \multirow[t]{4}{*}{ PAFC } & $150-200$ & Anode: $H_{2} \rightarrow 2 H^{+}+2 e^{-}$ & Phosphoric & $>40$ \\
\hline & & & acid & \\
\hline & & Cathode: & & \\
\hline & & $\frac{1}{2} \mathrm{O}_{2}+2 \mathrm{H}^{+}+2 e^{-} \rightarrow \mathrm{H}_{2} \mathrm{O}$ & & \\
\hline \multirow[t]{4}{*}{$\mathrm{MCFC}$} & $600-700$ & Anode: $\mathrm{H}_{2}+\mathrm{CO}_{3}^{2-} \rightarrow$ & $\mathrm{Li} / \mathrm{K} / \mathrm{Na}$ & 45 \\
\hline & & $\mathrm{H}_{2} \mathrm{O}+\mathrm{CO}_{2}+2 e^{-}$ & carbonate & \\
\hline & & Cathode: & & \\
\hline & & $\frac{1}{2} \mathrm{O}_{2}+\mathrm{CO}_{2}+2 e^{-} \rightarrow \mathrm{CO}_{3}^{2-}$ & & \\
\hline \multirow{3}{*}{$\begin{array}{l}\text { SOFC } \\
(+)\end{array}$} & $200-700$ & Anode: $H_{2} \rightarrow 2 H^{+}+2 e^{-}$ & Barium cerate & 40 \\
\hline & & Cathode: & & \\
\hline & & $\frac{1}{2} \mathrm{O}_{2}+2 \mathrm{H}^{+}+2 e^{-} \rightarrow \mathrm{H}_{2} \mathrm{O}$ & & \\
\hline \multirow{4}{*}{$\begin{array}{l}\text { SOFC } \\
(-)\end{array}$} & 1000 & Anode: & Yttria- & 40 \\
\hline & & $\mathrm{H}_{2}+\mathrm{O}^{2-} \rightarrow \mathrm{H}_{2} \mathrm{O}+2 e^{-}$ & $\begin{array}{l}\text { stabilized } \\
\text { zirconia }\end{array}$ & \\
\hline & & Cathode: & & \\
\hline & & $\frac{1}{2} O_{2}+2 e^{-} \rightarrow{ }^{6} 6^{-}$ & & \\
\hline
\end{tabular}


Cells, Microbial Fuel Cells, Direct Carbon Fuel Cells, etc [32]. The key specifications of those fuel cells are listed in Table 5 .

Among all those types of fuel cells, the PEMFC is widely used in automotive industry. In aviation, it is very common to see that PEMFC and SOFC are the two types to be considered suitable. AFCs have been used for space, but the issue caused by $\mathrm{CO}$ and $\mathrm{CO}_{2}$ poisoning prevents its applicability for general aviation, while for MCFC, it is due to its low power density and the adoption of the electrolyte in molten phase [48].

Meanwhile, it is important to recognise the differences between road transportation and aviation applications. For road transportation, the manufacturers are looking for easy manufacturing and cheap cost suitable for massive production. As a result, the high cost of PEMFC, due to the use of noble metal as catalyst is normally under criticism. However, for aviation applications, especially for military and private transportation applications, metrics of performance such as speed, endurance, and payload, are more important than the purchase cost [49]. Therefore, the relative high cost of PEMFCs should be not considered as an obstacle for aviation applications.

The technical targets for integrated PEMFC power systems operating on direct hydrogen for transportation applications drafted by the U.S. Department of Energy (DOE) are listed in Table 6 where the targets exclude hydrogen storage, power electronics and electric drive. However, this target is more appropriate for the application of hydrogen fuel cell system for road transportation. For many aviation applications, the weight of the component is one of the utmost important factors need to be considered as it affects a number of performance such as speed, endurance, and payload etc. For largescale passenger and commercial aviation applications, it is estimated that a fuel/propulsion system specific power of $2 \mathrm{~kW} / \mathrm{kg}$ would be required [49], and it is important to set up specifications for FCs to be used in aviation industry and hence provide guidance to develop FC technology that is suitable for powering commercial aircraft. 
Table 6: Technical targets: $80-k W_{e}$ (net) integrated transportation fuel cell power systems operating on direct hydrogen [50]

\begin{tabular}{|c|c|c|c|c|}
\hline Characteristic & Units & $\begin{array}{r}2015 \\
\text { Status }\end{array}$ & $\begin{array}{r}2020 \\
\text { Targets }\end{array}$ & $\begin{array}{l}\text { Ultimate } \\
\text { Targets }\end{array}$ \\
\hline Peak energy efficiency & $\%$ & 60 & 65 & 70 \\
\hline Power density & $W / L$ & 640 & 650 & 850 \\
\hline Specific power & $W / k g$ & 659 & 650 & 650 \\
\hline Cost & $\$ / k W_{n e t}$ & 53 & 40 & 30 \\
\hline \multicolumn{5}{|l|}{$\begin{array}{l}\text { Cold start-up time to } 50 \% \text { of } \\
\text { rated power }\end{array}$} \\
\hline @ $-20^{\circ} \mathrm{C}$ ambient temperature & seconds & 20 & 30 & 30 \\
\hline$@+20^{\circ} \mathrm{C}$ ambient temperature & seconds & $<10$ & 5 & 5 \\
\hline \multicolumn{5}{|l|}{ Start-up and shutdown energy } \\
\hline $\begin{array}{l}\text { from @ }-20^{\circ} \mathrm{C} \text { ambient } \\
\text { temperature }\end{array}$ & MJ & 7.5 & 5 & 5 \\
\hline $\begin{array}{l}\text { from @ }+20^{\circ} \mathrm{C} \text { ambient } \\
\text { temperature }\end{array}$ & MJ & - & 1 & 1 \\
\hline $\begin{array}{l}\text { Durability in automotive drive } \\
\text { cycle }\end{array}$ & hours & 3900 & 5,000 & 5,000 \\
\hline Start-up / shutdown durability & cycles & - & 5,000 & 5,000 \\
\hline $\begin{array}{l}\text { Assisted start from low } \\
\text { temperature }\end{array}$ & ${ }^{\circ} \mathrm{C}$ & - & -40 & -40 \\
\hline $\begin{array}{l}\text { Unassisted start from low } \\
\text { temperature }\end{array}$ & ${ }^{\circ} \mathrm{C}$ & -30 & -30 & -30 \\
\hline
\end{tabular}




\section{Hydrogen Fuel cell system as main propulsion}

The use of hydrogen fuel cell to replace the conventional jet engine as the main power source for manned aircraft propulsion is still facing a lot of challenges. Only a handful of publications reported the use of hydrogen fuel cell to power the manned aircraft to complete the entire flight mission alone, without the need of additional power supply. One of the examples is the Antares DLR-H2 glider $[55,56]$. In 2009, it is reported that the $25 \mathrm{kWp}$ fuel cell powered Antares DLR-H2 successfully achieved a cruising range of $750 \mathrm{~km}$ with a flight time of $5 \mathrm{~h}$ [55]. However, it is identified that the climbing performance could be expected to improve with the addition of the hybrid system's power boost [56]. In September 2020, DLR is partner with MTU Aero Engines to equip the Do 228 aircraft with a hydrogen fuel cell and an electrical, single-sided propeller engine with over $500 \mathrm{~kW}$ shaft output. It is planned to make the demonstrator in 2026 [57]. In order for fuel cell system to be widely used as the main propulsion unit for the aircraft, it is vital to increase the gravimetric energy density, i.e. develop ultralight fuel cell system which is the main target for fuel cell manufacturers [58].

On the other hand, the feasibility of using FC as main propulsion for UAVs has been widely approved. Compared with conventional internal combustion engines powered UAVs, [59] argued that fuel cell's static operation and low heat dissipation makes it a perfect candidate to facilitate the stealth nature of UAVs. Compared with batteries, which also shared the similar advantages, the lighter weight and higher energy density of fuel cells allow for greater mission range and the endurance can be increased up to $24 \mathrm{~h}$ compared to an average of one hour for battery powered UAVs. In addition, the modularity of fuel cells enables them to be used for small-scale applications such as UAVs, while conventional combustion engines suffers from low efficiencies when designed for small-scale applications.

The $24 \mathrm{~kg}$ Ion Tiger fuel cell powered UAV developed by [60] is capable of flying 24 hours successfully. In their work through hardware in the loop and analysis with Simulink models, the authors believed that hybridisation doesn't contribute to the further increase of endurance and they thought direct load following with the fuel cell is the best choice for long endurance. In 2013, the Ion Tiger demonstrated $48 h$ continuous un-refuelled flight using $1,340 \mathrm{~g}$ liquid hydrogen storage and total fuelled system mass of $5.87 \mathrm{~kg}$ 
[61]. The design of a 500W PEMFC powered UAV was presented in [62]. The power plant has an advanced balance of plant including variable cathode flow rate control, liquid cooling, self-humidification and variable period anode purging. The aircraft structure and aerodynamics have been designed incorporating the opportunities and constraints of the fuel cell power plant. [61] demonstrated that liquid hydrogen (LH2) stored at low pressure, relative to compressed gaseous hydrogen (GH2), is a better option than GH2 stored at pressure up to $34.5 \mathrm{MPa}$ in terms of flight endurance. They also identify that to achieve low weight and low total heat leak are the challenges to the design and fabrication of LH2 storage systems for aviation applications. They also identified several topics for further research which includes the influence of mechanical processes on the rate of evaporation, more extensive use of vapor shielding for reduced heat lead, and LH2 level measurement in flight.

[63] presented a study to evaluate the plausibility of increasing the service ceiling of an UAV to 10,000 metres by substituting an internal combustion engine with a FC powered electric motor. Due to the low concentration of oxygen at such high altitude, the open cathode configuration for $\mathrm{FC}$ is no longer suitable and hence required an onboard storage of oxygen as well as hydrogen. The results indicated the UAV should be capable of ascending above $10,000 \mathrm{~m}$ with the described $\mathrm{FC}$ and gas storage system.

[64] introduced a conceptual design process for a small UAV based on energy and performance targets of the PEMFC system for a long endurance mission of the small UAV. The small UAV consists of airframe, avionics, hydrogen storage, PEM fuel cell and battery. The author claimed that the gravimetric power and energy densities of the PEMFC system affected endurance of the designed UAV, but the effect of the gravimetric energy density of the hydrogen storage system on endurance was much larger than that of gravimetric power density of the fuel cell. If the gravimetric power and energy densities are higher than $600 \mathrm{~W} / \mathrm{kg}$ and $1800 \mathrm{Wh} / \mathrm{kg}$, respectively, flight endurance of the UAV will be longer than 24 hours.

To use hydrogen fuel cell as main propulsion source for aviation is still under evaluation and exploration. Similar to automotive industry, high energy and power density of fuel cell is also desirable in aviation. Meanwhile, there are other considerations for the application of fuel cell system in aviation, such as closed-cathode structure for high altitude flight due to low 
oxygen concentration in the ambient air where other factors may also need to be considered, for instance operating at low temperature, insulation and anti-icing etc.

\section{Fuel cell system as hybrid propulsion}

Compared with single propulsion system, a hybrid system possesses a number of advantages as summarised in [65]. Those include the reducing size of the hybrid system with respect to the required average power; the energy demand in the transient state allows fast variations which may be difficult to be met by a single propulsion component such as fuel cell or battery; the hybrid propulsion system can continue operating when component is malfunctioning; and lastly, the hybrid system has the capability to deal with intermittent availability of renewable energy sources.

\subsection{Fuel cell - Conventional Jet Engine hybridisation}

FC systems, particularly the SOFC system can be integrated with the conventional jet engine. This is driven by the fact that thermal efficiency of traditional combustion engines is lower than the efficiency of a fuel cell, and there is a difficulty in improving the combustion temperature, hence the thermal efficiency of engines due to the limitation of the engine material [66].

The integration of SOFC with gas turbine (GT) brings a number of benefits. High-grade waste heat from SOFC can be used in gas turbine to help drive the air compressor and hence improve the system efficiency. The long durability of SOFCs enables long mission lengths of UAVs and aircraft. Although low atmospheric pressure presents a difficulty in fuel cell cooling, stack cooling can be facilitated by high temperature operation [54].

SOFC can directly hybridise with conventional jet engine. In this topology, the heat generated from SOFC will be used to heat up the compressed air into the cathode channel and the oxygen depleted air will expand through the gas turbine.

[54] investigated the different SOFC/GT configuration for high-altitude long-endurance UAVs in order to maximise overall efficiency, reduce the fuel consumption and realise a one-week endurance target. The authors found 
that, compared with a single-stack design, modularise the fuel cell stack capacity into a number of discrete stacks so that fuel is distributed in parallel while air is fed in series can significantly increase the overall system efficiency.

After investigating the performance of engine-integrated catalytic partial oxidation $(\mathrm{CPOx})$ reactors and SOFCs with three gas turbine engine types (turbojet, combined exhaust turbofan, separate exhaust turbofan), [67] found that fuel efficiency can be increased by upto $8 \%$ while the configuration can provide factors of 3 more electric power than generator-based systems.

[68] introduced a lightweight SOFC design hybridised with a gas turbine and battery, and optimised component sizing and operation with the fuel consumption for maximum aircraft payload. The study focused on four different aircraft: the Fokker F70 (represents the regional aircraft), Boeing 787-8, and Airbus A300 (represents the core commercial aviation platforms), and A380 (represents the extreme jumbo sized aircraft). Different from previous studies considering develop advance high efficiency distributed propulsion system to compensate the mass added by electric power systems, this study only considered the side-by-side performance of fuel cells against existing turbofan engines. The results show that fuel cells can power much larger aircraft than were previously considered feasible, although novel fuel cell designs are necessary to compete with next generation gas turbine technology.

SOFC/GT integration can be further developed into turbine-less jet engine. This turbine-less engine not only utilised SOFC waste heat to supplement thrust by heating compressed air from an SOFC driven propulsor, but also use SOFC to replace the turbine and battery to provide electric power for the compressor. [69] evaluated the performance of the turbine-less jet engine which integrated with a SOFC and steam injection. The results demonstrated a significant improvement of the turbine-less engine in terms of specific impulse and specific thrust. In their further researches, they have evaluate the performance of the SOFC hybrid jet engine while considering the effect of pressure ratio and flight altitude [66], the pressure ratios, combustor exit temperature, flight Mach number and flight altitude [70], and fuel types [71], as well as other studies in the safe operating zone [72] and exergy $[73]$.

There are research work focus on the design and performance analysis, 
system control and optimisation. [74] carried out a "Well-to-Wing" efficiency analysis of liquid hydrogen produced through biomass gasification for SOFC/GT system and found the huge entropy loss in the preheating process. The influence of fuel cell stack operating conditions on degradation was widely investigated in literature, but such degradation effects on the performance of a fuel cell gas turbine hybrid system is not deeply considered, hence [75] developed five control strategies to mitigate degradation effects in fuel cell gas turbine hybrids. [76] optimised the gas turbine while considering the SOFC degradation. [77, 78] design and evaluate the operating strategies for a SOFC/GT hybrid system equipped with anode and cathode ejectors which are more reliable and low-cost in maintenance than blowers. It must be noticed that those research do not specifically taking aviation applications into consideration. Most of the them are for general utilisation of SOFC/GT hybrid structure, for instance, for stationary applications. The installation and operation requirements and the harsh environmental conditions of UAVs and aircraft are not considered.

It is true that there are certain drawbacks of using SOFCs, such as low power densities, not suitable for repetitive start-up/shut-down cycles, long start-up time, not mechanically robust enough for transportation applications, and poor dynamic response that is not able to satisfy the power demand of aviation applications [54]. In order to compete with the advancement of gas turbine technology, several research challenges should be addressed, which includes the system design, integration, dynamic response, control and optimisation particularly in the aviation context as summarised in this section.

\subsection{Fuel cell - electric hybridisation}

The major drawback prevents the use of battery as main power source for aviation application is its low energy density and long charging time. Its low power dynamics may also prevents the UAVs to conduct certain manoeuvres required fast power response. In order to increase the endurance, increasing the number of battery packs is not a practical solution due to weight and space constraints [11].

Ultracapacitors (UCs) normally have a high power density but low energy density. The recent review unveiled that, the state-of-the-art UCs commonly 
have power density around $10 \mathrm{~kW} / \mathrm{kg}$ and can be as high as $198 \mathrm{~kW} / \mathrm{kg}$, while the energy density is around $10 \mathrm{Wh} / \mathrm{kg}$ [79]. UCs can provide quick response to the peak power demand for UAVs during takeoff and sudden manoeuvres. On the other hand, fuel cell system is a promising candidate to increase the endurance of UAVs due to its high energy density and short refuelling time. In the hybridisation, the most favourable fuel cell type is the PEM FC, they are commonly combined with other power sources, such as battery, solar cells and ultracapacitor to satisfy the power demand.

With a modified commercially available PEM fuel cell stack, [14] successfully flew the fuel cell/battery hybrid small UAV (SUAV) for 2 hours with maximum takeoff weight of $1500 \mathrm{~g}$. Such configuration significantly extend the endurance of battery powered SUAVs which is normally 60-90 minutes. A hybrid fuel cell/battery propulsion system was developed and tested by [80]. The system also included the catalytic hydrolysis of sodium borohydride $\left(\mathrm{NaBH}_{4}\right)$ for hydrogen production. The fuel cell is used to meet the power demand during cruising while both the battery and the fuel cell systems provide the power required for the more power-demanding take-offs and manoeuvres. The authors found that the fuel cell systems are more efficient for long endurance flights of UAVs when compared with battery powered UAVs. They also identified that, to further improve the endurance of long flights for UAVs, it is essential to reduce the weight of stacks hence to increase the system energy density. [81] investigated the integration of a hybrid power system for a small UAV which consists of hydrogen fuel cell, photovoltaic panels and battery. The simulation based on the data acquired through bench tests of the power systems demonstrated that the UAV endurance increased from $470 \mathrm{~min}$ to $970 \mathrm{~min}$. However, in this system, the system will use the battery power until its voltage dropped below nominal, when the microcontroller switches to fuel cell, and when the battery gets recharged by the PV panels, the microcontroller switches to battery as the motor power source. [82] simulated the performance of a solar/hydrogen system for a high altitude long endurance aircraft. The regenerative fuel cell can be used as an electrolyser to produce hydrogen when excess solar electricity is available, as well as a fuel cell to consume hydrogen to produce electricity. However, in this work, the power consumption of the propeller was determined as a function of the aircraft weight in steady flight and in still air. [83] analysed the performance of drones powered by two propulsion systems, i.e. PEM fuel cell (with a support of a small $6800 m A h$ lithion ion battery) and lithium-ion 
batteries, from an economical point of view and carried life cycle assessments for both drones. Compared with battery powered drone, as the fuel cell size is fixed as it only depends on the features of the UAV, the limiting factor is given by the hydrogen storage. Due to the low commercial diffusion of fuel cells, it is expected that the cost will be higher. However, when considering the lifetime of both fuel cell and battery, it is worth noting that $20,000 h$ fuel cell lifetime is about three times than that of batteries which is around $6700 h$. Therefore, a reduction of costs is observed by authors when they are normalised by the lifetime hours of the systems, and the authors also expected further cost reductions due to the continuous development and spread of fuel cell technology.

The use of fuel cell as hybrid propulsion for manned military and commercial air vehicles is still under exploration. In 2008, Boeing successfully accomplished flight tests for a PEM FC and lithium-ion batteries powered two-seat aircraft [84]. [85] also demonstrated the feasibility of fuel cell hybrid propulsion system for a two-seat aircraft which consisted the $20 \mathrm{kWp}$ fuel cell system and Li-Po batteries. With total $H_{2}$ mass capacity of $1.2 \mathrm{~kg}$, the test flight achieved a record maximum speed of $135 \mathrm{~km} / \mathrm{h}$ and maximum endurance of $39 \mathrm{~min}$.

Power management strategy (PMS) is very important for hybrid propulsion system. It distributes the power demand to various power sources to complete the flight mission. The PMS is expected to optimally spilt the power demand between resources while considering the constraints such as efficiency, response speed, fuel consumption, power requirement, and flight conditions, in order to achieve an efficient energy usage and to enable high performance operation of power sources while extending their liftspan [11]. In general, the power management strategy for the hybrid electric systems can be active or passive. The main difference is the use of power electronic devices, such as DC/DC converter for most of the cases. Active power management is implemented via the power electronic devices, while passive ones only adjust the voltages of different power sources at the main DC bus for instance, either by direct connection or using power diodes. Active power management enables the implementation of more sophisticated control algorithms and will be able to recover energy during braking or descending to further reduce the fuel consumption and hence the overall system efficiency. However, there is an argument that passive power management is more suit- 
able for UAVs [86]. This is mainly due to the use of heavy inductors that act as filters in the DC/DC converters drastically limits the possibility of their application in lightweight UAVs . A brief summary of the developed power management strategies for UAVs is listed in Table 7.

There are research in analysing the performance of hybrid fuel cell power systems based on passive power management strategy.

[87] evaluated the performance of hybrid power system in surveillance and remote-sensing UAVs for missions with different cruise speeds and climb rates. The authors claimed that the performance of the fuel cell can deviate significantly from its steady-state polarisation curve for short periods of time, and suggested that the careful selection of fuel cell/battery combination to match the mission profile can increase overall performance and reduce fuel consumption. The performance of the passive hybrid power control system for a lightweight UAV that is capable of ascending up to the high troposphere $(10,000 \mathrm{~m})$ was evaluated in [86]. The passive power system used two power diodes for regulation, and the steady state performance demonstrated a good robustness and an increase of efficiency of the stack by more than 7\%. [88] developed a dedicated test bench for hardware-in-the-loop (HWIL) simulation of a FC based hybrid electrical propulsion system for small UAVs. They found that the fuel cell dynamics can have a significant impact on mission performance. In [56], a passive hybrid system was developed and two diodes were used to replace the DC/DC converter, such system has the ability to recharge the battery without a $\mathrm{DC} / \mathrm{DC}$ converter, and the results also demonstrated the capability of the quick response of the battery output to compensate for the delay in fuel cell output response, so that such hybrid system is applicable to high-frequency electric loads. [89] is also based on passive power management. At the low load, the fuel cell will recharge battery. Fuel cell will meet the power demand for the cruise flight while both fuel cell and battery will provide power together for the more power demanding takeoff phase.

In the active power management system, the more sophisticated control strategy provides more flexibility which can contribute to further adjustment of the system's performance, such as hydrogen consumption, the state of charges of the batteries/supercapacitors, the overll system efficiency, the stresses on each source which impact their life cycle [92]. State machines 
Table 7: Summary of the developed power management strategies for UAVs

\begin{tabular}{|c|c|c|}
\hline Ref & Hybridisation & Power/Energy Management \\
\hline$[87]$ & PEM fuel cell / batteries & Passive power-management \\
\hline$[86]$ & $\begin{array}{l}\text { High temperature PEMFC / } \\
\text { lithium-polymer batteries }\end{array}$ & ditto \\
\hline$[88,89]$ & $\begin{array}{l}\text { PEM fuel cell / lithium- } \\
\text { polymer batteries }\end{array}$ & ditto \\
\hline$[56]$ & $\begin{array}{l}\text { PEM fuel cell / lithium-ion } \\
\text { batteries }\end{array}$ & ditto \\
\hline$[90]$ & PEM fuel cell / Li-ion battery & $\begin{array}{l}\text { Adaptive Neuro Fuzzy Infer- } \\
\text { ence System }\end{array}$ \\
\hline$[91]$ & $\begin{array}{l}\text { PEM fuel cell / lithium batter- } \\
\text { ies }\end{array}$ & State machines control \\
\hline$[92]$ & $\begin{array}{l}\text { PEM fuel cell / Li-ion batteries } \\
\text { / Supercapacitors }\end{array}$ & $\begin{array}{l}\text { Comparison of various active } \\
\text { methods including state ma- } \\
\text { chines control }\end{array}$ \\
\hline$[93,94]$ & $\begin{array}{l}\text { PEM fuel cell / lithium- } \\
\text { polymer batteries }\end{array}$ & Active power management \\
\hline$[95]$ & $\begin{array}{l}\text { Solar Cells, PEMFC, Li-Po } \\
\text { battery }\end{array}$ & $\begin{array}{l}\text { Rule based active power man- } \\
\text { agement, compared with pas- } \\
\text { sive method }\end{array}$ \\
\hline$[96]$ & $\begin{array}{l}\text { Solar Cells, PEMFC, Li-ion } \\
\text { battery }\end{array}$ & $\begin{array}{l}\text { Rule based active power man- } \\
\text { agement, compared with pas- } \\
\text { sive method }\end{array}$ \\
\hline$[97]$ & $\begin{array}{l}\text { Solar Cells, PEMFC, lithium } \\
\text { battery }\end{array}$ & $\begin{array}{l}\text { Rule based active power man- } \\
\text { agement }\end{array}$ \\
\hline
\end{tabular}


control strategy was implemented for a fuel cells/battery hybrid UAV system [91]. The system was tested on a test bed with a 15 mins flight profile with different SOC initial conditions. [92] compared the impact of various energy management strategies during a typical emergency landing scenario for a hybrid aircraft which consists of fuel cells, lithium-ion batteries, and supercapacitors. The authors found that the state machines control scheme provided better efficiency and stresses on the battery and supercapacitor. The classical PI control scheme had the lowest fuel consumption and more use of the battery energy, while the frequency decoupling and fuzzy logic scheme achieved the lowest fuel-cell stress and the lowest use of the battery energy but with more fuel consumption and lower overall efficiency. As a result, the authors concluded that the ideal energy management system should be a multi-scheme strategy that difference scheme is chosen based on a specific prioritised criteria. [93] noticed the significant difference between the dynamic performance of the fuel cell system and its static polarisation curve, and suggested that there is a need for detailed measurements. Meanwhile, the battery plays a crucial role in response to dynamic load changes and protects the FC from membrane dehydration and fuel starvation. The power management board can use FC to charge the battery, however, the AeroStack power management board used in [94] only recharges the battery to at most $70 \%$ of its capacity and charging can take up to nearly $2 \mathrm{~h}$. As the recharging requires fuel consumption by the fuel cell, a compromise is needed between the boost capability of the battery and the total mission endurance. A rule based power management strategy was developed by [96] for a $200 \mathrm{~W}$ class, low-speed, long endurance UAV that ustilised solar cells, PEMFC and Li-ion battery as its power sources. Within its $3.8 \mathrm{~h}$ flight test, the PMS successfully demonstrated its feasibility of keeping the power sources within their proper operational bounds when responding to various power requirements associated with the flight conditions and maintains a target state-of-charge of $45 \%$. Compared with passive power management strategy, the authors claimed that the passive method failed to maintain an appropriate reserve battery power level under some operating conditions while this reserve battery power is very important to safeguard the operation of UAV in case of a malfunction of the power electronics or PMS, and it also contributes to the reduce size and weight of the FC system. However, many flight related conditions were neglected in this study. In [97], the UAV was powered by solar cells, a PEMFC and a battery. Maximum power point track device is associated with the solar cells to extract maximum power from the so- 
lar irradiance hence enhance the overall efficiency and reduce the number of solar cells. The fuel cell system also included a sodium borohydride-based hydrogen generator for hydrogen production. Solid state relays were used to select different power sources to satisfy the power demand.The system was successfully tested for a period of $1.5 h$ flight.

However, it must be noticed that many of the power management strategies used for simulation are the application of previously developed strategies for hybrid vehicles, tram or even for distributed generation systems etc. It is true that the fundamental philosophy of power management is more or less similar, but for those methods to be successfully applied for aviation applications, it is also important to consider the specific environmental and flight related conditions in aviation.

\section{Fuel cell system as auxiliary power}

An on-board auxiliary power unit (APU) is used for satisfying the nonpropulsive power demand. These include demand for engine start-up, environmental control, primary and secondary surface control, braking, landing gear, etc. In conventional aircraft design, those systems use one or a combination of energy types which include electrical, hydraulic, mechanical, and pneumatic energy, as listed in Table 8. However, there are drawbacks associated with all different energy types which include the sacrifice of overall engine efficiency in the process of harvesting hydraulic and pneumatic energy. Therefore, in order to improve various of aircraft characteristics, such as efficiency, emissions, reliability, and maintenance costs, it is important to replace existing non-electric systems with electrical systems. [98].

The integrated drive generator (IDG) which is conventionally used to change the variable speed of the jet engine to constant speed via mechanical means has been eliminated from the newer commercial transport aircraft. Using a generator control unit, the main engine generator which is directly coupled to the jet engine via a gearbox can provide a constant voltage and variable frequency AC power supply. Therefore, power converter is required to convert power from one form to another to support the loads that was original associated with an IDG. It becomes very important to consider the weight, volume, reliability, and performance of power electronic converters 
Table 8: Comparison of major subsystems of conventional aircraft and MEA (summarised information based on $[98,99]$ )

\begin{tabular}{|c|c|c|}
\hline Subsystem & Conventional Aircraft & MEA \\
\hline Power system & $\begin{array}{l}\text { Generator(s) connected to en- } \\
\text { gine or conventional APU to } \\
\text { generate electric power, pneu- } \\
\text { matic, and hydraulic power }\end{array}$ & $\begin{array}{l}\text { Electric APU to generate elec- } \\
\text { tric power, replaced previ- } \\
\text { ously hydraulic, mechanical, } \\
\text { and pneumatic powered sub- } \\
\text { systems }\end{array}$ \\
\hline $\begin{array}{l}\text { Engine start- } \\
\text { up }\end{array}$ & $\begin{array}{l}\text { Use the pneumatic power gen- } \\
\text { erated from conventional APU } \\
\text { to drive the air turbine starter } \\
\text { (ATS) }\end{array}$ & $\begin{array}{l}\text { Electric start-up, eliminate the } \\
\text { air ducts and ATS }\end{array}$ \\
\hline $\begin{array}{l}\text { Environmental } \\
\text { control system }\end{array}$ & $\begin{array}{l}\text { Use bleed air obtained from } \\
\text { one or two of the compressor } \\
\text { stages of the main engine }\end{array}$ & $\begin{array}{l}\text { Compressors utilizing electric } \\
\text { power is to regulate the tem- } \\
\text { perature and pressure in the } \\
\text { cabin. }\end{array}$ \\
\hline $\begin{array}{l}\text { On-board inert } \\
\text { gas generation } \\
\text { system }\end{array}$ & $\begin{array}{l}\text { Use a pneumatic system to in- } \\
\text { fuse the gas tank with nitrogen }\end{array}$ & $\begin{array}{l}\text { Use electrical separation mod- } \\
\text { ule to separate the oxygen in } \\
\text { the air to fill the empty space } \\
\text { in the tank }\end{array}$ \\
\hline $\begin{array}{l}\text { Hydraulic } \\
\text { related func- } \\
\text { tions, e.g. } \\
\text { primary and } \\
\text { secondary } \\
\text { surface con- } \\
\text { trol, braking, } \\
\text { landing gear, } \\
\text { etc. }\end{array}$ & $\begin{array}{l}\text { Hydraulic and pneumatic ac- } \\
\text { tuators }\end{array}$ & $\begin{array}{l}\text { Electro-hydraulic actuators } \\
\text { (EHAs) or electromechanical } \\
\text { actuators (EMAs) }\end{array}$ \\
\hline $\begin{array}{l}\text { Electrical } \\
\text { energy storage }\end{array}$ & $\begin{array}{l}\text { Mainly battery, only used in } \\
\text { emergency condition and for } \\
\text { APU start-up }\end{array}$ & $\begin{array}{l}\text { Electrical energy storage used } \\
\text { in all flight phases }\end{array}$ \\
\hline
\end{tabular}


and electric machines to be used in the aircraft industry [98].

As APU is built into the vehicle and the load demand to be satisfied could range from less than a kilowatt up to $500 \mathrm{~kW}$ on large commercial aeroplanes, therefore separation of the main propulsion system from the APU is a good strategy to optimise the overall energy consumption [59].

[100] deployed fuel cell systems on a Boeing 787-8 air plane, carried out hardware analysis and thermodynamic simulation. The fuel cell system is used to satisfy some of the electrical and thermal demand, and will not eliminate the need for either the main engine generators or auxiliary power unit. Compared the performance of the aircraft with and without fuel cell systems, some of the key findings of the research including:

- The fuel cell and hydrogen storage should be located together in either the fairing area or the tail cone area. Although they are the heaviest hardware components, it is possible to save $50-100 \mathrm{~kg}$ in system mass when fuel cell is located closed to both the hydrogen supply and the electrical load.

- Air cooled systems are not preferred, as they require a large increase in current air handling units' capacities, as well as have large weight and volumes, hence large performance penalties.

- Adding a heat exchanger to cool and fuel cell's exhaust and recovering the water is beneficiary despite the additional equipment and cooling drag.

- For maximum performance benefits, fuel cell system should be used at full load for the entire flight. Therefore, the support of loads such as the in-flight entertainment and galley are attractive.

- Fuel cell system that meets the DOE-target will provide an overall performance boost to the air plane, as they are currently responsible to the majority of the system mass and volume.

- The use of fuel cell system can provide an electrical generation efficiency gain of over $30 \%$. This could result in a savings of over 20,000 metric tons of $\mathrm{CO}_{2}$ emissions per year if implemented on a fleet of 1000 airplanes such as the 787 . 


\section{Multi-functionality of hydrogen fuel cell}

Last but not least, the introduction of hydrogen and fuel cell system to the aircraft also brings other benefits, such as the additional provision of water.

The water stored on an aircraft is not only for direct drinking by the passengers and the crew, but also consumed in multiple ways, such as making hot beverages and soups, for reconstituting baby food, or for the provision of hot towels for refreshing purposes, and can also be used for toilet flush, hand wash, cabin air humidification, etc $[43,101,102]$. The water tanks onboard are normally oversized becasue they are rarely emptied and for domestic or European-bound aircraft, the tanks are generally refilled at the home airport to avoid costs [102] or to allow a return flight when there are concerns about the water quality at the destination airport [103].

[101] explored the use of hydrogen as a carrier of water and energy. By studying the quality of water produced from a $1 \mathrm{~kW}$ residential-scale PEMFC and a $300 \mathrm{~kW}$ molten carbonate fuel cell (MCFC), the results shown that water produced by the PEMFC meets nearly all US Environmental Protection Agency (USEPA) and World Health Organization (WHO) drinking water requirements while the pipe material corrosion products (nickel, aluminium and manganese) found in water can be easily controlled. The author also claimed that the amount of water produced by the PEMFC is sufficient to satisfy drinking water needs in a typical American household if a recovery efficiency of $40 \%$ is reached.

On the other hand, for many years, fuel tank explosions have been considered as a constant threat due to serious aviation safety implications. Since 1960, fuel tank explosion had caused 18 aeroplanes been damaged or destroyed. The investigations concluded that one of the reasons is due to the centre wing fuel tank contained flammable vapours in the ullage (the portion of the fuel tank not occupied by liquid fuel) [104]. As a result, one of the solutions proposed by the Federal Aviation Administration (FAA) is the introduction of inerting. FAA defined a tank is considered inert when average oxygen concentration within each compartment of the tank is $12 \%$ or less from sea level up to 10,000 feet altitude, then linearly increasing from $12 \%$ at 10,000 feet to $14.5 \%$ at 40,000 feet altitude, and extrapolated linearly 
above that altitude [104]. The oxygen depleted cathode exhaust gas could be used to replace nitrogen for inerting the kerosene tank, hence reduce the need for currently used nitrogen tanks or air separation modules [43].

In evaluating the feasibility of multiple function of using fuel cell systems for civil aircraft, [43] found that under the laboratory set-up, the hydrogen pressure tank based architecture displayed the highest potential for longrange aircraft applications in terms of on-board water generation and provision of inerting gas, when compared with hydrogen cryogenic tank, hydrogen hydride tank and reformer configuration.

[103] suggested that the operation of FC can be adjusted according to the flight phase and desired mode, such as focusing on generating electric power during on-ground operations and focusing on provision of inert gas and water during the flight phase although it is decrease the FC efficiency while the power generated can still be used as auxiliary power supply.

\section{On-board hydrogen storage}

In order to introduce hydrogen into the aircraft, the design of storage should be considered carefully. [105] presented a preliminary design model for aircraft liquid hydrogen tanks for both foam and multilayer insulations. Such design requires a carefully balance between mechanical and thermal requirements. Meanwhile, the achievable tank gravimetric storage density is affected by the aircraft type as shown in the conducted parametric studies. [38] compared the energy efficiency of kerosene- and hydrogen-fuelled aircraft, and found that the use of hydrogen can lead to an increase of energy efficiency upto $12 \%$ for long-range aircraft. They also evaluate the impact of the tank configuration between top tanks and integral tanks, and concluded that the use of top tanks considerably increase the tank weight particularly for medium-range aircraft. [106] discussed the implementation of liquid hydrogen fuel tanks in future commercial aeroplanes focusing on the sizing of the fuel tank structure and its behaviour under critical loading conditions. Fuel tanks are sized according to the mission requirements and geometrical restrictions of a conventional mid-range commercial aeroplane. The authors found that implementing two integral liquid hydrogen fuel tanks forward and afterward in the fuselage of a conventional civil airliner signif- 
icantly reduces the available space for the payload. Finite element analysis shows that a typical fuselage semi-monocoque structure together with pressure bulk-heads (domes) is a good alternative to resist the high tank internal pressure. For hydrogen-fuelled aircraft, the design of lightweight but effective insulated cryogenic tanks is the key. This is true especially when considering the operation of aircraft in the harsh thermal environment associated with hypersonic speeds [107] . After examining the use of different insulation systems for cryogenic hypersonic tanks for a Mach 5 flight, [107] argued that a combination of foam and fully load-bearing aerogel blanket leads to the lightest tank, with a gravimetric efficiency of $73 \%$.

\section{Conclusion}

In this paper, the status of the application of hydrogen and fuel cell technology in aviation is reviewed and following challenges and potential issues are believed need to be addressed in order to further increase the penetration of hydrogen and fuel cell applications in aviation industry:

- Compared with automotive industry, there is no clear targets and roadmap defined for enhancing the application of hydrogen and FC system in aviation. It is clear that the adaptation of hydrogen and fuel cell for aviation requires more considerations depends on the aerial vehicle types, not only the desired power and energy density, but also the requirements such as insulation, vibration, operation under low temperature and high altitude condition, but also the structure and configuration of the fuel cell unit that need to be satisfied the constraint of the aviation applications. As a result, this targets and roadmap may not like the automotive one but maybe a set of documents/combinations for various applications depends on their range, operation conditions, vehicle size etc.

- Hydrogen and fuel cell system can play a number of roles in aviation to reduce the carbon emission, for instance, as the main propulsion source, as part of the hybrid propulsion system, as APU etc. At current stage, the use of hydrogen fuel cell system as main propulsion source for long range commercial aircraft doesn't seem to be feasible. In the near or medium term, the jet engine will still be the dominant propulsion 
for long rang commercial aircraft. The SOFC jet engine hybridisation is good configuration that improves system efficiency and reduce fuel consumption. The fuel cell electric hybridisation configuration is more suitable for smaller aircraft and UAVs. The by-product from fuel cell system, as reviewed in the paper, can be use for water supply or for inerting. The hybridisation configuration and the mulitple functionality of fuel cell system require a systematic design, control and optimisation not only to operate the fuel cell system effectively to satisfy the demand to complete a flight mission, but also to maximise the benefits and efficiency of fuel cell system for different aerial vehicles and under different flight missions.

- Instead of the retrofit of existing fossil fuel powered aircraft, the new design of hydrogen and fuel cell powered aircraft that especially consider the location, integration of hydrogen fuel cell unit, the storage method and mechanism, and the roadmap of gaining aviation authorities' certification is also need to be addressed.

\section{References}

[1] Boeing, Commercial Market Outlook 2019-2038, Boeing, 2019.

[2] IATA, Economic per formance of the airline industry, [Accessed 15-08-2020] (2020).

URL https : / / www . iata . org / en / iata-repository / publications / economic-reports / airline-industry-economic-performance-june-2020-report/

[3] J. Burgués, S. Marco, Environmental chemical sensing using small drones: A review, Science of The Total Environment (2020) 141172.

[4] R. Kellermann, T. Biehle, L. Fischer, Drones for parcel and passenger transportation: A literature review, Transportation Research Interdisciplinary Perspectives 4 (2020) 100088.

[5] R. M. Elavarasan, R. Pugazhendhi, Restructured society and environment: A review on potential technological strategies to control the covid-19 pandemic, Science of The Total Environment (2020) 138858. 
[6] J. EUCHI, Do drones have a realistic place in a pandemic fight for delivering medical supplies in healthcare systems problems? (2020).

[7] B. Graver, K. Zhang, D. Rutherford, CO2 emissions from commercial aviation, 2018, [Accessed 23-09-2019] (2019).

URL https://theicct.org/sites/default/files/publications/ ICCT_CO2-commercl-aviation-2018_20190918.pdf

[8] European Commission, Reducing emissions from aviation, [Accessed 03-09-2019] (n.d.).

URL https : / / ec . europa . eu / clima / policies / transport / aviation_en

[9] U. E. Programme, Emissions gap report 2019, [Accessed 15-06-2020] (2019).

URL https : / / www . unenvironment . org / resources / emissions-gap-report-2019

[10] Aerospace Technology Institute, Raising Ambition, Aerospace Technology Institute, 2016.

[11] M. N. Boukoberine, Z. Zhou, M. Benbouzid, A critical review on unmanned aerial vehicles power supply and energy management: Solutions, strategies, and prospects, Applied Energy 255 (2019) 113823.

[12] I. Gál, D. Rohacs, J. Rohacs, Developing the unmanned unconventional cargo airplanes with hybrid propulsion system, in: 31st Congress of the International Council of Aeronautical Sciences (ICAS), 2018.

[13] J. Hoelzen, Y. Liu, B. Bensmann, C. Winnefeld, A. Elham, J. Friedrichs, R. Hanke-Rauschenbach, Conceptual design of operation strategies for hybrid electric aircraft, Energies 11 (1) (2018) 217.

[14] T. Kim, S. Kwon, Design and development of a fuel cell-powered small unmanned aircraft, International Journal of Hydrogen Energy 37 (1) (2012) 615-622.

[15] A. Thielmann, A. Sauer, R. Isenmann, M. Wietschel, Technology roadmap energy storage for electric mobility 2030, Fraunhofer ISI (2013). 
[16] Energy.Gov, Us drive electrochemical energy storage technical team roadmap, [Accessed 17-08-2020] (2017).

[17] Battery2030, Inventing the sustainable batteries of the future - research needs and future actions, [Accessed 17-08-2020] (2020).

[18] Airbus, The future is electric, [Accessed 16-06-2020] (2018).

URL https: / / www . airbus . com / newsroom/news / en / 2018/07 / the-future-is-electric.html

[19] Ampaire, Press release - ampaire announces first public electric flight, [Accessed 17-06-2020] (2019).

URL https://www . ampaire.com/news/public-reveal-060619

[20] Eviation, Alice specification, [Accessed 16-06-2020] (n.d.).

URL https://www.eviation.co/aircraft/

[21] Aerospace Technology, Extra 330le electric aircraft, [Accessed 17-062020] (n.d.).

URL https : / / www . aerospace-technology . com / projects / extra-330le-electric-aircraft/

[22] Kittyhawk, Kittyhawk, [Accessed 16-06-2020] (n.d.).

URL https://kittyhawk.aero/

[23] Lilium, Lilium, [Accessed 16-06-2020] (n.d.).

URL https://lilium.com/

[24] NASA, Nasa armstrong fact sheet: Nasa x-57 maxwell, [Accessed 16-06-2020] (2018).

URL https : / / www . nasa . gov / centers / armstrong / news / FactSheets/FS-109.html

[25] Pipistrel, Alpha electro: The world's first 2-seat electric trainer, [Accessed 16-06-2020] (n.d.).

URL https : / / www . pipistrel-aircraft . com / aircraft / electric-flight/alpha-electro/\#tab-id-1

[26] SolarImpulse Foundation, Solar impulse: Around the world to promote clean technologies, [Accessed 17-06-2020] (n.d.).

URL https://aroundtheworld. solarimpulse.com/adventure 
[27] Uber, Fast forwarding to the future of on-demand, urban aviation, [Accessed 16-06-2020] (n.d.).

URL https://www.uber.com/us/en/elevate/uberair/

[28] Volocopter, Volocity: The superior air taxi for the inner city, [Accessed 16-06-2020] (n.d.).

URL https://www.volocopter.com/en/product/

[29] N. Manthey, Wright electric works on large electric passenger plane, [Accessed 17-06-2020] (2020).

URL https : / / www . electrive . com / 2020 / 02 / 02 / wright-electric-works-on-large-electric-passenger-plane/

[30] CISION PRWeb, Zunum aero and safran helicopter engines join forces to deliver electric commercial aircraft with unparalleled efficiency, [Accessed 16-06-2020] (2018).

URL http : / / www . prweb . com / releases / zunum _ aero _ and _ safran _ helicopter _ engines _ join _ forces _ to _ deliver _ electric_commercial_aircraft_with_unparalleled_efficiency/ prweb15814645.htm

[31] P. Fieltsch, H. Flämig, K. Rosenberger, Analysis of charging behavior when using battery electric vehicles in commercial transport, Transportation Research Procedia 46 (2020) 181-188.

[32] F. Zhang, P. Zhao, M. Niu, J. Maddy, The survey of key technologies in hydrogen energy storage, International Journal of Hydrogen Energy 41 (33) (2016) 14535-14552.

[33] H. Nojoumi, I. Dincer, G. Naterer, Greenhouse gas emissions assessment of hydrogen and kerosene-fueled aircraft propulsion, International Journal of Hydrogen Energy 34 (3) (2009) 1363-1369.

[34] M. Janić, Greening commercial air transportation by using liquid hydrogen (lh2) as a fuel, International Journal of Hydrogen Energy 39 (29) (2014) 16426-16441.

[35] Y. Bicer, I. Dincer, Life cycle evaluation of hydrogen and other potential fuels for aircrafts, International Journal of Hydrogen Energy 42 (16) (2017) 10722-10738. 
[36] S. R. Pereira, T. Fontes, M. C. Coelho, Can hydrogen or natural gas be alternatives for aviation?-a life cycle assessment, International Journal of Hydrogen Energy 39 (25) (2014) 13266-13275.

[37] C. Koroneos, A. Dompros, G. Roumbas, N. Moussiopoulos, Advantages of the use of hydrogen fuel as compared to kerosene, Resources, Conservation and Recycling 44 (2) (2005) 99-113.

[38] D. Verstraete, On the energy efficiency of hydrogen-fuelled transport aircraft, International Journal of Hydrogen Energy 40 (23) (2015) 73887394.

[39] E. Baharozu, G. Soykan, M. B. Ozerdem, Future aircraft concept in terms of energy efficiency and environmental factors, Energy 140 (2017) $1368-1377$.

[40] A. Baroutaji, T. Wilberforce, M. Ramadan, A. G. Olabi, Comprehensive investigation on hydrogen and fuel cell technology in the aviation and aerospace sectors, Renewable and Sustainable Energy Reviews 106 (2019) 31-40.

[41] D. Cecere, E. Giacomazzi, A. Ingenito, A review on hydrogen industrial aerospace applications, International Journal of Hydrogen Energy 39 (20) (2014) 10731-10747.

[42] G. Renouard-Vallet, M. Saballus, G. Schmithals, J. Schirmer, J. Kallo, K. A. Friedrich, Improving the environmental impact of civil aircraft by fuel cell technology: concepts and technological progress, Energy \& Environmental Science 3 (10) (2010) 1458-1468.

[43] G. Renouard-Vallet, M. Saballus, P. Schumann, J. Kallo, K. A. Friedrich, H. Müller-Steinhagen, Fuel cells for civil aircraft application: On-board production of power, water and inert gas, Chemical Engineering Research and Design 90 (1) (2012) 3-10.

[44] İ. Yılmaz, M. İlbaş, M. Taştan, C. Tarhan, Investigation of hydrogen usage in aviation industry, Energy conversion and management 63 (2012) 63-69. 
[45] S. Sharma, S. K. Ghoshal, Hydrogen the future transportation fuel: From production to applications, Renewable and sustainable energy reviews 43 (2015) 1151-1158.

[46] C. Acar, I. Dincer, Impact assessment and efficiency evaluation of hydrogen production methods, International journal of energy research 39 (13) (2015) 1757-1768.

[47] Energy Institute, Energy essentials - a guide to hydrogen, [Accessed 01-07-2020] (2020).

URL https://knowledge.energyinst.org/collections/hydrogen

[48] G. Correa, F. Borello, M. Santarelli, Sensitivity analysis of stack power uncertainty in a pemfc-based powertrain for aircraft application, International Journal of Hydrogen Energy 40 (32) (2015) 10354-10365.

[49] J. Garche, C. K. Dyer, P. T. Moseley, Z. Ogumi, D. A. Rand, B. Scrosati, Encyclopedia of electrochemical power sources, Elsevier, 2009.

[50] U.S. Department of Energy, Doe technical targets for fuel cell systems and stacks for transportation applications, [Accessed 16-04-2020] (n.d.).

URL https : / / www · energy - gov / eere / fuelcells / doe-technical-targets-fuel-cell-systems-and-stacks-transportation-applicatio

[51] M. Boll, M. Corduan, S. Biser, M. Filipenko, Q. H. Pham, S. Schlachter, P. Rostek, M. Noe, A holistic system approach for short range passenger aircraft with cryogenic propulsion system, Superconductor Science and Technology 33 (4) (2020) 044014.

[52] B. Khandelwal, A. Karakurt, P. R. Sekaran, V. Sethi, R. Singh, Hydrogen powered aircraft: The future of air transport, Progress in Aerospace Sciences 60 (2013) 45-59.

[53] D. Verstraete, Long range transport aircraft using hydrogen fuel, International Journal of Hydrogen Energy 38 (34) (2013) 14824-14831.

[54] P. Aguiar, D. Brett, N. Brandon, Solid oxide fuel cell/gas turbine hybrid system analysis for high-altitude long-endurance unmanned aerial 
vehicles, International Journal of Hydrogen Energy 33 (23) (2008) 7214-7223.

[55] S. Barrett, Fuel cells power first takeoff for dlr's antares aircraft, Fuel Cells Bulletin (2009).

[56] A. Nishizawa, J. Kallo, O. Garrot, J. Weiss-Ungethüm, Fuel cell and liion battery direct hybridization system for aircraft applications, Journal of Power Sources 222 (2013) 294-300.

[57] Fuel Cells Bulletin, DLR and MTU Aero Engines to study fuel cell aircraft propulsion 2020 (9) (2020) 7.

[58] Fuel Cell Bulletin, Hydrogenics contract for aircraft fuel cells, air liquide takes stake, Fuel Cells Bulletin 2019 (1) (2019) 14. doi:https://doi.org/10.1016/S1464-2859(19)30033-1.

URL http : / / www . sciencedirect . com/science/article/pii / S1464285919300331

[59] O. Z. Sharaf, M. F. Orhan, An overview of fuel cell technology: Fundamentals and applications, Renewable and Sustainable Energy Reviews 32 (2014) 810-853.

[60] K. Swider-Lyons, R. Stroman, G. Page, M. Schuette, J. Mackrell, J. Rodgers, Hydrogen fule cell propulsion for long endurance small uvas, in: AIAA Centennial of Naval Aviation Forum" 100 Years of Achievement and Progress", 2011, p. 6975.

[61] R. O. Stroman, M. W. Schuette, K. Swider-Lyons, J. A. Rodgers, D. J. Edwards, Liquid hydrogen fuel system design and demonstration in a small long endurance air vehicle, International Journal of Hydrogen Energy 39 (21) (2014) 11279-11290.

[62] T. H. Bradley, B. A. Moffitt, D. N. Mavris, D. E. Parekh, Development and experimental characterization of a fuel cell powered aircraft, Journal of Power Sources 171 (2) (2007) 793-801.

[63] J. Renau, A. Lozano, J. Barroso, J. Miralles, J. Martín, F. Sánchez, F. Barreras, Use of fuel cell stacks to achieve high altitudes in light unmanned aerial vehicles, International Journal of Hydrogen Energy 40 (42) (2015) 14573-14583. 
[64] T. H. Oh, Conceptual design of small unmanned aerial vehicle with proton exchange membrane fuel cell system for long endurance mission, Energy Conversion and Management 176 (2018) 349-356.

[65] Z. Pan, L. An, C. Wen, Recent advances in fuel cells based propulsion systems for unmanned aerial vehicles, Applied Energy 240 (2019) 473485.

[66] Z. Ji, J. Qin, K. Cheng, H. Liu, S. Zhang, P. Dong, Thermodynamic analysis of a solid oxide fuel cell jet hybrid engine for long-endurance unmanned air vehicles, Energy Conversion and Management 183 (2019) $50-64$.

[67] D. F. Waters, C. P. Cadou, Engine-integrated solid oxide fuel cells for efficient electrical power generation on aircraft, Journal of Power Sources 284 (2015) 588-605.

[68] J. M. Collins, D. McLarty, All-electric commercial aviation with solid oxide fuel cell-gas turbine-battery hybrids, Applied Energy 265 (2020) 114787.

[69] Z. Ji, J. Qin, K. Cheng, F. Guo, S. Zhang, P. Dong, Thermodynamics analysis of a turbojet engine integrated with a fuel cell and steam injection for high-speed flight, Energy 185 (2019) 190-201.

[70] Z. Ji, J. Qin, K. Cheng, C. Dang, S. Zhang, P. Dong, Thermodynamic performance evaluation of a turbine-less jet engine integrated with solid oxide fuel cells for unmanned aerial vehicles, Applied Thermal Engineering 160 (2019) 114093.

[71] Z. Ji, J. Qin, K. Cheng, F. Guo, S. Zhang, P. Dong, Comparative performance analysis of solid oxide fuel cell turbine-less jet engines for electric propulsion airplanes: Application of alternative fuel, Aerospace Science and Technology 93 (2019) 105286.

[72] Z. Ji, J. Qin, K. Cheng, F. Guo, S. Zhang, C. Zhou, P. Dong, Determination of the safe operation zone for a turbine-less and solid oxide fuel cell hybrid electric jet engine on unmanned aerial vehicles, Energy (2020) 117532. 
[73] Z. Ji, J. Qin, K. Cheng, H. Liu, S. Zhang, P. Dong, Advanced exergy and graphical exergy analyses for solid oxide fuel cell turbine-less jet engines, Journal of Power Sources 456 (2020) 227979.

[74] A. Fernandes, T. Woudstra, P. Aravind, System simulation and exergy analysis on the use of biomass-derived liquid-hydrogen for sofc/gt powered aircraft, International Journal of Hydrogen Energy 40 (13) (2015) $4683-4697$.

[75] V. Zaccaria, D. Tucker, A. Traverso, Operating strategies to minimize degradation in fuel cell gas turbine hybrids, Applied energy 192 (2017) 437-445.

[76] A. Cuneo, V. Zaccaria, D. Tucker, A. Sorce, Gas turbine size optimization in a hybrid system considering sofc degradation, Applied Energy 230 (2018) 855-864.

[77] J. Chen, J. Li, D. Zhou, H. Zhang, S. Weng, Control strategy design for a sofc-gt hybrid system equipped with anode and cathode recirculation ejectors, Applied Thermal Engineering 132 (2018) 67-79.

[78] J. Chen, Y. Chen, H. Zhang, S. Weng, Effect of different operating strategies for a sofc-gt hybrid system equipped with anode and cathode ejectors, Energy 163 (2018) 1-14.

[79] J. M. Baptista, J. S. Sagu, U. W. KG, K. Lobato, State-of-the-art materials for high power and high energy supercapacitors: Performance metrics and obstacles for the transition from lab to industrial scale-a critical approach, Chemical Engineering Journal 374 (2019) 1153-1179.

[80] K. Kim, T. Kim, K. Lee, S. Kwon, Fuel cell system with sodium borohydride as hydrogen source for unmanned aerial vehicles, Journal of power sources 196 (21) (2011) 9069-9075.

[81] M. Gadalla, S. Zafar, Analysis of a hydrogen fuel cell-pv power system for small uav, International Journal of Hydrogen Energy 41 (15) (2016) $6422-6432$.

[82] R. Barbosa, B. Escobar, V. M. Sanchez, J. Hernandez, R. Acosta, Y. Verde, Sizing of a solar/hydrogen system for high altitude long 
endurance aircrafts, International journal of hydrogen energy 39 (29) (2014) 16637-16645.

[83] N. Belmonte, S. Staulo, S. Fiorot, C. Luetto, P. Rizzi, M. Baricco, Fuel cell powered octocopter for inspection of mobile cranes: Design, cost analysis and environmental impacts, Applied energy 215 (2018) $556-565$.

[84] F. Escarti, Boeing fuel cell plane in manned aviation first, Fuel Cells Bulletin 4 (1) (2008) 70146-9.

[85] G. Romeo, F. Borello, G. Correa, E. Cestino, Enfica-fc: Design of transport aircraft powered by fuel cell \& flight test of zero emission 2seater aircraft powered by fuel cells fueled by hydrogen, International journal of hydrogen energy 38 (1) (2013) 469-479.

[86] J. Renau, F. Sánchez, A. Lozano, J. Barroso, F. Barreras, Analysis of the performance of a passive hybrid powerplant to power a lightweight unmanned aerial vehicle for a high altitude mission, Journal of Power Sources 356 (2017) 124-132.

[87] A. Gong, J. L. Palmer, G. Brian, J. R. Harvey, D. Verstraete, Performance of a hybrid, fuel-cell-based power system during simulated small unmanned aircraft missions, International Journal of Hydrogen Energy 41 (26) (2016) 11418-11426.

[88] D. Verstraete, J. R. Harvey, J. L. Palmer, Hardware-in-the-loop simulation of fuel-cell-based hybrid-electrical uav propulsion, in: 28th International congress of the aeronautical sciences, 2012.

[89] T. Kim, Nabh4 (sodium borohydride) hydrogen generator with a volume-exchange fuel tank for small unmanned aerial vehicles powered by a pem (proton exchange membrane) fuel cell, Energy 69 (2014) $721-727$.

[90] L. Karunarathne, J. T. Economou, K. Knowles, Model based power and energy management system for pem fuel cell/li-ion battery driven propulsion system (2010).

[91] Z. Yang, T. Lei, Z. Lin, H. Fu, X. Zhang, The testing platform of hybrid electric power system for a fuel cell unmanned aerial vehicle, in: 
2018 IEEE International Conference on Electrical Systems for Aircraft, Railway, Ship Propulsion and Road Vehicles \& International Transportation Electrification Conference (ESARS-ITEC), IEEE, 2018, pp. $1-8$.

[92] S. N. Motapon, L.-A. Dessaint, K. Al-Haddad, A comparative study of energy management schemes for a fuel-cell hybrid emergency power system of more-electric aircraft, IEEE transactions on industrial electronics 61 (3) (2014) 1320-1334.

[93] D. Verstraete, K. Lehmkuehler, A. Gong, J. R. Harvey, G. Brian, J. L. Palmer, Characterisation of a hybrid, fuel-cell-based propulsion system for small unmanned aircraft, Journal of power sources 250 (2014) 204211.

[94] D. Verstraete, A. Gong, D. D.-C. Lu, J. L. Palmer, Experimental investigation of the role of the battery in the aerostack hybrid, fuel-cell-based propulsion system for small unmanned aircraft systems, International Journal of Hydrogen Energy 40 (3) (2015) 1598-1606.

[95] B. Lee, P. Park, C. Kim, S. Yang, S. Ahn, Power managements of a hybrid electric propulsion system for uavs, Journal of mechanical science and technology 26 (8) (2012) 2291-2299.

[96] B. Lee, S. Kwon, P. Park, K. Kim, Active power management system for an unmanned aerial vehicle powered by solar cells, a fuel cell, and batteries, IEEE transactions on aerospace and electronic systems 50 (4) (2014) 3167-3177.

[97] B. G. Gang, S. Kwon, Design of an energy management technique for high endurance unmanned aerial vehicles powered by fuel and solar cell systems, International Journal of Hydrogen Energy 43 (20) (2018) 9787-9796.

[98] B. Sarlioglu, C. T. Morris, More electric aircraft: Review, challenges, and opportunities for commercial transport aircraft, IEEE transactions on Transportation Electrification 1 (1) (2015) 54-64.

[99] J. Chen, C. Wang, J. Chen, Investigation on the selection of electric power system architecture for future more electric aircraft, IEEE Transactions on Transportation Electrification 4 (2) (2018) 563-576. 
[100] J. W. Pratt, L. E. Klebanoff, K. Munoz-Ramos, A. A. Akhil, D. B. Curgus, B. L. Schenkman, Proton exchange membrane fuel cells for electrical power generation on-board commercial airplanes, Applied energy 101 (2013) 776-796.

[101] J. E. Tibaquirá, K. D. Hristovski, P. Westerhoff, J. D. Posner, Recovery and quality of water produced by commercial fuel cells, International Journal of Hydrogen Energy 36 (6) (2011) 4022-4028.

[102] H. Handschuh, J. O. Dwyer, C. C. Adley, Bacteria that travel: the quality of aircraft water, International journal of environmental research and public health 12 (11) (2015) 13938-13955.

[103] H. C. Champion, S. Kabelac, Multifunctional fuel cell system for civil aircraft: Study of the cathode exhaust gas dehumidification, International Journal of Hydrogen Energy 42 (49) (2017) 29518-29531.

[104] Federal Aviation Administration, Reduction of Fuel Tank Flammability in Transport Category Airplanes, https : //www . federalregister . gov/documents /2008/07/21/E8-16084/ reduction-of-fuel-tank-flammability-in-transport-category-airplanes, [Online; accessed 03-12-2020] (2008).

[105] D. Verstraete, P. Hendrick, P. Pilidis, K. Ramsden, Hydrogen fuel tanks for subsonic transport aircraft, International Journal of Hydrogen Energy 35 (20) (2010) 11085-11098.

[106] A. Gomez, H. Smith, Liquid hydrogen fuel tanks for commercial aviation: Structural sizing and stress analysis, Aerospace Science and Technology 95 (2019) 105438.

[107] S. Sharifzadeh, D. Verstraete, P. Hendrick, Cryogenic hydrogen fuel tanks for large hypersonic cruise vehicles, International Journal of Hydrogen Energy 40 (37) (2015) 12798-12810. 